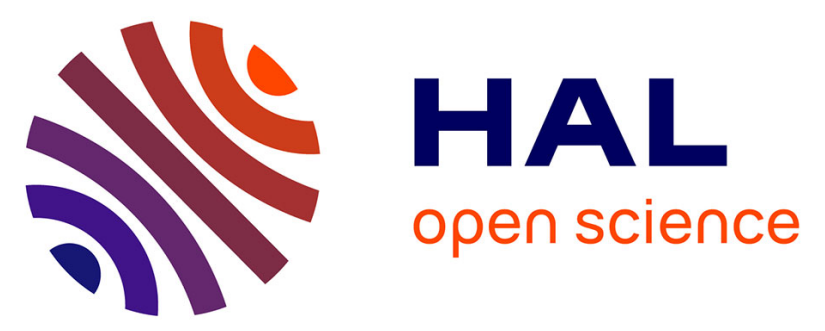

\title{
Side effect of grain protectants on biological control agents: How Hyptis plant extracts affect parasitism and larval development of Dinarmus basalis
}

\author{
A. Sanon, N. Ba, L. C. B. Dabire, R.C.H. Nibie, Jean Paul Monge
}

\section{- To cite this version:}

A. Sanon, N. Ba, L. C. B. Dabire, R.C.H. Nibie, Jean Paul Monge. Side effect of grain protectants on biological control agents: How Hyptis plant extracts affect parasitism and larval development of Dinarmus basalis. Phytoparasitica, 2011, 39 (3), pp.215-222 10.1007/s12600-011-0162-8 . hal01310124

\author{
HAL Id: hal-01310124 \\ https://hal.science/hal-01310124
}

Submitted on 1 May 2016

HAL is a multi-disciplinary open access archive for the deposit and dissemination of scientific research documents, whether they are published or not. The documents may come from teaching and research institutions in France or abroad, or from public or private research centers.
L'archive ouverte pluridisciplinaire HAL, est destinée au dépôt et à la diffusion de documents scientifiques de niveau recherche, publiés ou non, émanant des établissements d'enseignement et de recherche français ou étrangers, des laboratoires publics ou privés. 


\section{Sanon A, Ba MN, Dabiré LCB, Nébié RCH, Monge JP. Side effects of grain protectants on biological control agents: how Hyptis plant extracts affect parasitism and larval development...}

Article in Phytoparasitica · July 2011

Impact Factor: 0.9 · DOI: 10.1007/s12600-011-0162-8

CITATION

1

5 authors, including:

Antoine Sanon

University of Ouagadougou

80 PUBLICATIONS 476 CITATIONS

SEE PROFILE

Roger Charles Nebié

Centre National de Recherche Scientifique...

28 PUBLICATIONS 308 CITATIONS

SEE PROFILE
READS

66
Malick Ba

Consultative Group on International Agricu...

53 PUBLICATIONS 185 CITATIONS

SEE PROFILE 
Side effect of grain protectants on biological control agents: How Hyptis plant extracts affect parasitism and larval development of Dinarmus basalis

\author{
A. Sanon ${ }^{1}$, M. N. Ba ${ }^{2}$, L. C. B. Dabiré ${ }^{2}$, R. C. H. Nébié ${ }^{3}$, J. P. Monge ${ }^{4}$
}

\title{
Affiliations
}

1 Laboratoire d'Entomologie Fondamentale et Appliquée, UFR/SVT, Université de Ouagadougou, Burkina Faso, ${ }^{2}$ Laboratoire d'Entomologie Agricole, Institut de l'Environnement et de Recherches Agricoles (INERA), Burkina Faso, ${ }^{3}$ Département substances naturelles, Institut de Recherches en Sciences Appliquées et technologies (IRSAT), Burkina Faso, ${ }^{4}$ Institut de recherche sur la Biologie de l'Insecte (UMR CNRS 6035) Université de Tours, France.

Short title: How Hyptis plant species affect Dinarmus basalis

Correspondence to: Sanon Antoine, Université de Ouagadougou, 03 BP 7021 Ouagadougou 03 Burkina Faso, E-mail: sanonant@yahoo.fr, Tel: +226 503073 72, Fax: +226 50307242 


\begin{abstract}
Dinarmus basalis Rondani (Hymenoptera: Pteromalidae), an ectoparasitoid of Bruchid pest of stored cowpeas, is a potential biological control agent. We investigated whether grain protectants from Hyptis spicigera and H. suaveolens (Lamiaceae) disturb parasitism and post embryonic growth of the parasitoid. When cowpeas containing bruchid larvae were treated before being placed in the presence of $D$. basalis females, the rate of parasitism decreased on average up to 24 and $47 \%$ respectively in the presence of leaves dry powder and essential oils from both plant species. The estimated larval mortality was higher on treated (9.5 to $28.6 \%$ ) than on non treated parasitized hosts $(2.8 \%)$, depending on the plant species and the plant extract tested. Additional larval mortality was higher for essential oil, and for H. suaveolens.. An in-depth analysis of the pre-imaginal development in capsules adapted for this purpose showed that without treatment, mortality was recorded only for eggs and the two first larval stages. In the presence of treatment, mortality not only significantly increased on eggs but also spanned over all other pre-imaginal stages. Pre-imaginal development was also significantly extended in the presence of treatment, depending on the type of extract and dose used. In conclusion, both plant species exert acute toxicity on $D$. basalis larvae and also act as growth inhibitors. These results provide additional information that enable to move towards a harmonious use of allelochemical compounds from plants while protecting biocontrol agents from their adverse effects.
\end{abstract}

Key words: Plant extracts, Side effects, Growth inhibition, IPM 


\section{Introduction}

Postharvest grain storage is a major constraint for cowpeas, the most important legume grain crop in West-Africa. The cowpea weevil Callosobruchus maculatus Fab. (Coleoptera: Bruchidae) larvae can destroy all the grains within 6 months of storage (Ouedraogo, et al., 1996). Among the control method integrated pest management appear to be one of the most promising strategy. This approach includes using of plant material with insecticidal or repulsive properties based on farmers' endogenous practices. However the IPM context also involved the innovative biological control strategy.

During the past ten years, using plants with insecticidal or repulsive properties was ranked top of the planned endogenous Bruchid and other storage pest control methods (Golob et al. 1999; Boeke et al. 2001; Boeke et al. 2004a,b; Sanon et al. 2006a,b; Iskber et al., 2009; Ndomo et al. 2010). Scientific research on this topic mainly aimed at developing the most efficient alternatives to chemicals and likely to offset the disadvantages of the exclusive and sometimes unreasonable use of pesticides (Huis, 1991; Sanon et al. 2006a; Mbata and Brewster, 2009). Plant material can produce odors that repel or confuse adult beetles, hence likely to prevent the invasion or cause the emigration of treated stocks and can also bear secondary metabolites that may be toxic (Boeke et al. 2004a).

Biological control of $C$. maculatus by augmentative releases of the larvophagous parasitoid Dinarmus basalis has been investigated in several ecological zones of West Africa (Ouédraogo et al. 1996; Amevoin 1998; Sanon, et al. 1998; Amevoin et al. 2007). Previous studies revealed that releases of appropriate numbers of $D$. basalis adults at the beginning of cowpea storage reduce the pest population by $90 \%$ and enables to maintain the quality of the seeds after 6 months of storage (Sanon et al. 1998). So far the lacking of an appropriate and economically efficient mass production of parasitoids does not allow the deployment of any biological control program with D. basalis for C. maculatus control at large scale. In an ideal 
situation, plant products could be easily available to everyone at affordable costs, easily and safely applicable, toxic and repellent only against target organisms (Boeke et al. 2001). For a conservative biological control program perspective it may be therefore useful to explore all possible effects of plant products on not target organisms to develop a global IPM strategy. Hyptis spicigera Lam and Hyptis suaveolens L. Poit are two Labiatae species used to control cowpea storage pests (Keita et al. 2000; Boeke et al. 2001; Sanon et al. 2006a,b). Leaves dry powder and essential oils are known to be toxic towards Callosobruchus maculatus (Keita et al. 2000; Sanon et al. 2006a; Ilboudo et al. 2010). On the other hand, few data are available on the effects of these plant-based treatments on the natural enemies of pests. Obviously findings from our previous studies (Sanon et al. 2006b) revealed that females D. basalis are repelled by odors of leaves dry powder and essential oils of $H$. suaveolens. When given a choice, $D$. basalis females avoid treated hosts and rather parasitize untreated hosts. However, no information is available regarding a situation of no choice when parasitoids may be in confined stores with treated hosts. Treated seeds containing hosts may repel the females, at very short distance during the phase of exploration, and limit their ability to find hosts and to parasitize those (Sanon et al. 2006b). Allelochemical compounds contained in the leaves dry powder and essential oils of these predominant mono and sesquiterpenoid plants (Onayade et al. 1990; Kini et al. 1993; Peerzada, 1997; Tchoumbougnang et al. 2005) may also inhibit the growth of larvae as it has been observed among many insects pest (Hu, 1998; Agarwal et al. 2001). However, such effects were rarely observed on natural enemies.

In this study we investigated how leaves dry powder and essential oils from both Hyptis plant species could affect in controlled conditions the parasitic activity of D. basalis females and the development of the parasitoid offspring. The cowpea seeds, containing host larvae, were treated before being placed in the presence of females of parasitoid to determine if their parasitic fitness was disturb, and hence, examine the effects on pre-imaginal growth. 
The influence of a continuous exposure of $D$. basalis larvae to different doses of leaves dry powder and essential oils on larval mortality and pre-imaginal development was also analyzed.

\section{Material and methods}

\section{Origin of insects and conditions of study}

The C. maculatus and D. basalis strains used for this study were collected from insects emerging from cowpea seeds harvested late in September 2007 in the region of Ouagadougou in Burkina Faso. Upon emergence, insects were kept in the laboratory with usual rearing methods (Ouédraogo et al. 1996; Gauthier, 1996) for at least 3 generations prior to the tests. Laboratory rearing conditions $\left(33^{\circ}: 23^{\circ} \mathrm{C}, 12 \mathrm{~h}: 12 \mathrm{~h} ; 70 \pm 10 \% \mathrm{r}\right.$. h. with synchronization between the thermoperiod and the photoperiod) were close to those of the zones of origin of the insects. Under such conditions, the C. maculatus L4 larvae used for parasitoid development were obtained 16-18 days after eggs were laid. The average time for D. basalis development ranged from 16 to 17 days.

\section{Plant material used}

Samples of Hyptis spicigera and H. suaveolens were collected late in October, in the central region of Burkina Faso. The aerial parts of the plants were dried at $30^{\circ} \mathrm{C}$ for 72 hours in darkness and crushed in order to obtain a fine powder. Additional plant material was extracted by the hydro-distillation technique during 3 hours in a modified Clevenger-type glass apparatus (Craveiro et al. 1976). The extracted crude essential oil was stored in hermetically sealed dark glass flasks and kept under refrigeration at $4^{\circ} \mathrm{C}$ until use without any prior purification. For this experiment we used sub lethal doses for bruchids (Sanon et al. 2006a, b) $5 \mathrm{~g}$ and $10 \mathrm{~g}$ for leaves dry powder and $5 \mu \mathrm{L}$ and $10 \mu \mathrm{L}$ for essential oils. 


\section{Consequences of pre-treatment of hosts with leaves dry powder and essential oils on the parasitic ability of $\boldsymbol{D}$. basalis females and the production of offspring}

The objective of this experiment was to determine whether D. basalis females, placed in the presence of previously treated hosts, could parasitize these hosts and produce offspring. To obtain adequate hosts for $D$. basalis development, lots of $200 \mathrm{~g}$ of healthy cowpeas were placed into Plexiglas boxes $(17 \times 11 \times 4 \mathrm{~cm})$ in the presence of 50 pairs of C. maculatus adults for 24 hours. Two days later, the cowpeas were examined and those bearing one Bruchid egg were selected and placed in batches of 50 seeds. These lots were monitored and 16 to 18 days after, C. maculatus L4 larvae or pupae (favourite hosts of D. basalis) were obtained. Each batch of 50 seeds was then placed in a 1-L jar to analyze the D. basalis parasitic activity. In a first experiment five (5) inseminated $D$. basalis females were placed in each of the 10 jars for 24 hours without any additional treatment. In a second experiment, the seeds were first treated separately with $10 \mathrm{~g}$ of leaves dry powder or $5 \mu \mathrm{L}$ of essential oil from each plant, for 48 hours. The leaves dry powder was poured in the jar and shacked to equally disperse the powder on seeds. The essential oil was applied by means of a micropipette on a piece of Whatman filter paper $\left(\mathrm{S}=4 \mathrm{~cm}^{2}\right)$ previously glued on the sides of the jar. Seventy two (72) hours after the treatment, five $D$. basalis inseminated females were placed in the jars for 24 hours. Preliminary studies have shown that the doses used do not kill the L4 larvae and nymphs of C. maculatus active in seeds nor adult parasitoids $72 \mathrm{~h}$ after treatment (Sanon et al. 2006a). For each experiment each batch of 10 jars represents one replicate and 10 replicates were done. The seeds of the first 5 replications were monitored until the emergence of insects (Bruchids and parasitoids) to count the insects emerging in each case. Seeds of the other 5 replications were moistened and then dissected to count parasitized hosts. Data collected enabled to first determine the reduction in the rate of parasitism by plant-based treatments by 
computing the ratio between the number of parasitized hosts in the presence and absence of Hyptis. Then, D. basalis larval mortality rate was estimated based on the ratio of average number of insects emerging in each experimental situation and the average number of parasitized hosts under the same situation.

\section{Effects of a continuous exposure of immature stages of $D$. basalis to leaves dry powder and essential oils from Hyptis on pre-imaginal development}

To better examine and track the progress of the pre-imaginal phase, D. basalis development was monitored in capsules similar to those used by Jaloux et al. (2004). Each capsule has a lower part designed to receive the host for parasitoid development, and an upper part embedded in the lower part and covering the host. C. maculatus L4 Larvae, hosts for the parasitoids development were extracted from the cowpea seeds and poured into the lower part of each capsule. It was then covered by the upper part with 3 previously drilled holes to allow the parasitoid female to reach its host, and to lay eggs there. Studies by Cortesero et al. (1993) and Gauthier (1996) showed that the development of the parasitoids could be done in the capsules without disruption. The prepared capsules were placed for 24 hours with 4 days old D. basalis inseminated females. At the end of this period, the capsules were observed with binocular magnifying glasses to select those with parasitized hosts. These were basically plated under Petri dishes $(\varnothing=55 \mathrm{~mm})$ using modeling paste. Then, the dishes were put into 1$\mathrm{L}$ jars to monitor the parasitoid development. For each plant species, 2 doses of leaves dry powder ( 5 and $10 \mathrm{~g})$ and two doses of essential oils $(5$ and $10 \mu \mathrm{L})$ were poured into the jars until the end of the development. An untreated control was also formed. In each case, the development was followed for 25 individuals and the experiment 5 times replicated. The capsules were observed each day to determine the progress of $D$. basalis development, from egg to adult. Post embryonic development includes 3 larval stages and one pupae (Rasplus, 
1989). The duration of each individual development was determined with accuracy, and also when applicable, the stage at which development was interrupted.

\section{Statistical analysis}

Data were submitted to an ANOVA (SAS, version 8, 2001) and when ANOVAs were significant, means were separated by the Student-Newman-Keuls test at the $5 \%$ level. For preimaginal mortality square root transformation of data $(\sqrt{ } \mathrm{x}+1)$ was computed to get homogeneity of the variance before ANOVAs.

\section{Results}

Consequences of pre-treatment of hosts with leaves dry powder and Hyptis essential oils on the parasitism by $D$. basalis females and the production of offspring

\section{Parasitism rate and Production of offspring}

When seeds containing bruchids larvae were treated with leaves dry powder or essential oils from both Hyptis plant species, the rates of parasitism by D. basalis females were significantly reduced $(\mathrm{P}<0.01)$ (Table 1$)$.

Pre-treatment based on leaves dry powder and essential oils from both plant species significantly reduced the number of $D$. basalis adults emerging from parasitized hosts (Table 1). Pre-treatment of the hosts significantly increased mortality among D. basalis immature stages for essential oils but not for leaves dry powder as compare to the control (Table 1).

Effects of continuous exposure of immature stages of $D$. basalis to leaves dry powder and essential oil from Hyptis plant species on pre-imaginal development 
Both leaves dry powder and essential oil from Hyptis significantly affect D. basalis larval mortality_ $(\mathrm{P}<0.01)$ and mortality is higher with increase doses (Tables $2 \mathrm{a}$ and $2 \mathrm{~b})$. Mortality during $D$. basalis pre imaginal development was significantly higher with $H$. suaveolens than H. spicigera for both essential oils and leaves dry powder.

An analysis of the distribution of pre-imaginal mortality in control batches showed that mortality affected eggs, first 2 larval stages and L3-pupae (Tables 3a and 3b). However mortality was not significantly affected by the doses regardless of the plant species for leaves dry powder or essential oils.

Leaves dry powder and essential oil from both plant species significantly increased the $D$. basalis pre-imaginal development duration (Tables $4 \mathrm{a}$ and $4 \mathrm{~b}$ ).

\section{Discussion}

This study showed that pre-treatment of cowpeas containing bruchids larvae, of leaves dry powder or essential oil from both Hyptis plant species using sub lethal doses for bruchid, even72 hours prior to placing them with the parasitoid D. basalis, disturbed the capacity of females to parasitize these hosts. Moreover, mortality among immature stages of D. basalis developing on such hosts, and the total pre-imaginal development duration increased.

Disturbance in the capacity of parasitoid D. basalis to parasitize could be explained by the females' behaviors while searching and exploiting the hosts. Gauthier (1996), demonstrated that the choice of females to lay eggs or not on a host also depends on its quality, which is detected and evaluated during the exploration phase. Since cowpea seeds are able to absorb the volatile compounds from different plant extracts (Risha et al. 1990; Rahman and Schmidt, 1999; Sanon et al. 2002), it is assumed that these volatile compounds then either exert repulsion on females in contact with cowpeas during the host exploration phase, or inhibit female egg laying during the host quality evaluation, or moreover, exercise 
both effects at the same time. Previous studies, in choice situation, have shown that sub lethal doses of leaves dry powder or H. suaveolens essential oils reduced D. basalis females rates of parasitism and reproductive potential (Sanon et al. 2006b). Similarly, D. basalis larvae, active on hosts inside seeds soaked in volatile compounds, could have their development disturbed, which can even lead to an unusual high pre-imaginal mortality.

Close monitoring of pre-imaginal development in the capsules has confirmed these first findings highlighting an acute toxicity from leaves dry powder and essential oil from both Hyptis plant species on D. basalis pre imaginal stages. The susceptibility of D. basalis immature stages to Hyptis was different depending on the immature stage with greater sensitivity on eggs. Similar results were observed with the pest C. maculatus (Sanon et al. 2002; Ketoh et al. 2002; 2005). The higher pre-imaginal mortality induced by leaves dry powder and essential oils of $H$. suaveolens as compared to $H$. spicigera, may result from different chemical composition of both plant species extracts (Tchoumbougnang et al. 2005; Ilboudo et al. 2010). The essential oils from both Hyptis plant species share several compounds (particularly $\beta$-caryophyllène, $\alpha$ and $\beta$-pinene). However, 1,8 -cineole, the main component of $H$. suaveolens essential oil (Peerzada, 1997), is highly toxic towards Callosobruchus maculatus adults (Ilboudo et al. 2010). Interestingly, this component is lacking in H. spicigera essential oil (Kini et al. 1993). Therefore, 1,8-cineole may have contribute for the higher mortality induced by $H$. suaveolens.

In all cases, both plant species seem to increase mortality, especially during the last larval stages. This result could mean that the effect of the volatile compounds released by the plants accumulated during development, so that an individual who escaped a precise period of development could succumb later. The extension of the pre-imaginal development caused by extracts from both Hyptis species is the result of the disturbances in the development at precise stages without leading to the death of the insect. On the one hand, such disturbances 
could come from the anti-appetent effects produced by the allelochemical compounds (mainly terpenoids) in the tested plant extracts (Onayade et al. 1990; Kini et al. 1993). Such observations were made on larvae of several phytophagous insect species feeding on substrates containing terpenoid compounds (Avilla et al. 2000; Isman, 2000; Caballero et al. 2001). On the other hand, they could also come from an inhibition of the production of some digestive enzymes or enzymes involved in molting as observed with natural phenolic compounds (Torres et al. 2003). However, growth inhibiting effects have rarely been observed in parasitoids placed in the presence of insecticidal plant extracts used against their hosts.

This study has shown that treatment of cowpeas with extracts from $H$. spicigera and H. suaveolens could have adverse effects on the reproduction and development of the parasitoid D. basalis. Most of the previous studies have particularly highlighted the acute toxicity of allelochemical compounds on D. basalis adults (Ketoh et al. 2002; 2005; Sanon et al. 2002) or even their repulsive effects (Sanon et al. 2006b). As far as we know, this is the first time that the growth inhibiting effects of such treatments on the pre imaginal stages of this parasitoid have been demonstrated. It would be also relevant to determine the induced effects on the behavior and reproduction of insects surviving from these treatments for a better understanding of the issue in a storage situation. Already, the results provide reliable indications which may guide field practitioners in their search for a harmonious and complementary combination of the biological control and the use of allelochemical compounds as suggested by Ketoh et al. (2005). For a biological control based on conservation strategy of parasitoids it is important that farmers used the plant material in a manner that is effective and that would not affect the parasitoids a lot. In case of augmentative releases of parasitoids it may be recommended to delay the introduction of parasitoids in a 
store previously treated with allelochimical compounds. The conditions of such combinations are yet to be defined more acutely.

\section{Acknowledgements}

The authors wish to express their heartfelt thanks to the International Foundation for Science (IFS-OPCW) for supporting research relating to the effects of Hyptis plant species on bruchid pests and their natural enemies through a C/3393 Fellowship awarded to A. Sanon. The Institut de Recherche pour le Développement (IRD) is also thanked for allocating a CORUS grant (contract 6072) and facilitating exchanges between French Universities and the University of Ouagadougou.

\section{References}

Agarwal, M., Walia, S., Dhingra S., \& Khambay B. P. S., (2001). Insect growth inhibition, antifeedant and antifungal activity of compounds isolated/derived from Zingiber officinale Roscoe (ginger) rhizomes. Pest Management Science, 57, 289-300.

Amevoin, K., (1998). Activités reproductrices et réponses comportementales de Dinarmus basalis et d'Eupelmus vuilleti en présence de leur hôte Callosobruchus maculatus en zone guinéenne au Togo. Thèse de Doctorat, $152 \mathrm{p}$.

Amevoin, K., Sanon, A., Apossaba, M., \& Glitho, I. A., (2007). Biological control of bruchids infesting cowpea by the introduction of Dinarmus basalis (Rondani) (Hymenoptera: Pteromalidae) adults into farmers' stores in West Africa. Journal of Stored Product Research, 43, 240-247.

Avilla, J., Teixido, A., Velazquez, C., Alvarenga, N., Ferro, E., \& Canela, R., (2000). Insecticidal activity of Maytenus species (Celastraceae) nortriterpene quinone methides 
against codling moth, Cydia pomonella (L.) (Lepidoptera: Tortricidae). Journal of Agricultural and Food Chemestry, 48, 88-92.

Boeke, S.J., van Loon, J. J. A., van Huis, A., Kossou, D. K., \& Dicke, M., (2001). The use of plant material to protect stored leguminous seeds against seeds beetles: A review. Wageningen University Papers, 2001-3, Blackhyus Publishers.

Boeke, S. J., Baumgart, I. R., van Loon, J. J. A., van Huis, A., Dicke, M., \& Kossou, D. K., (2004a). Toxicity and repellence of African plants traditionally used for the protection of stored cowpea against Callosobruchus maculatus. Journal of Stored Products Research, 40, 423-438.

Boeke, S. J., Barnaud, C., van Loon, J. J. A., Kossou, D. K., van Huis, A., \& Dicke, M., (2004b). Efficacy of plant extracts against the cowpea beetle, Callosobruchus maculatus. International Journal of Pest Management, 50, 251-258.

Caballero, C., Castanera, P., Ortego, F., Fontana, G., Pierro, P., Savona, G., \& Rodriguez, B., (2001). Effects of ajugarins and related neoclerodane diterpenoids on feeding behaviour of Leptinotarsa decemlineata and Spodoptera exigua larvae. Phytochemistry 58, 249256.

Cortesero, A. M., Monge, J. P., \& Huignard, J., (1993). Response of the parasitoid Eupelmus vuilleti to the odours of the phytophagous host and its host plant in an olfactometer. Entomologia Experimentalis et Applicata, 69, 109-116.

Craveiro, A.A., Matos, F.J., \& Alencar, J.W. (1976). A simple and inexpensive steam generator for essential oils extraction. Journal of Chemical Education, 53, 652

Dugravot, S., Sanon, A., Thibout, E., \& Huignard, J., (2002). Susceptibility of Callosobruchus maculatus (Coleoptera: Bruchidae) and its parasitoid Dinarmus basalis (Hymenoptera: Pteromalidae) to sulphur-containing compounds. Consequences on 
biological control. Environmental Entomology, 31, 550-557.

Gauthier, N., (1996). Etude d'un ectoparasitoid solitaire Dinarmus basalis Rond. (Hymenoptera : Pteromalidae) en situation de compétition intra et interspécifique : activités reproductrices et réponses comportementales. Thèse de Doctorat, Tours, 183p.

Golob, P., Moss, C., Dales, M., Fidgen, A., \& Evans, J., (1999). The use of spices and medicinals as bioactive protectants for grains. FAO Agricultural Bulletin, 137.

Huis, Van A., (1991). Biological methods in bruchid control in the tropics: a review. Insect Science and its Application, 12, 87-102.

Ilboudo, Z., Dabiré, L. C. B., Nébié, R. C. H., Dicko, I. O., Dugravot, S., Cortesero, A. M., \& Sanon, A., (2010). Biological activity and persistence of four essential oils towards the main pest of stored cowpeas, Callosobruchus maculatus (F.) (Coleoptera: Bruchidae). Journal of Stored Product Research, 46, 124-128.

Iskber, A. A., Ozder, N., \& Saglam, O., (2009). Susceptibility of eggs of Tribolium confusum, Ephestia kuehniella and Plodia interpunctella to four essential oil vapors. Phytoparasitica, 37, 231-239.

Isman, M. B., (2000). Biopesticides based on phytochemicals. In: Phytochemical Biopesticides. Ed. by Koul, O.; Dhaliwal, G. S. Newark, NJ: Harwood Academic, Gordon and Breach Publishing, 1-12.

Jaloux, B., Sanon, A., Huignard, J. \& Monge, J. P., (2004). Interspecific Relationships Between the Solitary Ectoparasitoid, Eupelmus vuilleti (Crw.) (Eupelmidae), and Its Sympatric Species, Dinarmus basalis (Rond.) (Pteromalidae), in the Presence of Their Host, Callosobruchus maculatus Pic (Coleoptera Bruchidae). Journal of Insect Behavior, 17, 793-808 
Keita, M. S., Vincent, C., Schmit, J. P., Ramaswamy, S., \& Belanger, A., (2000). Effects of various essential oils on Callosobruchus maculatus F. (Col.: Bruchidae). Journal of Stored Product Research, 36, 355-364.

Ketoh, G. K., Glitho, A. I., \& Huignard, J., (2002). Susceptibility of the bruchid Callosobruchus maculatus (F.) and its parasitoid Dinarmus basalis (Rond.) (Hymenoptera Pteromalidae) to three essential oils. Journal of Economic Entomology, 95, 174-182.

Ketoh, G. K., Koumaglo, H. K., \& Glitho, I. A., (2005). Inhibition of Callosobruchus maculatus (Fab.) (Coleoptera: Bruchidae) development with essential oil extracted from Cymbopogon schoenanthus L. Spreng (Poaceae), and the wasp Dinarmus basalis Rondani (Hymenoptera: Pteromalidae). Journal of Stored Products Research, 41, 363371.

Kini, F., Kam, B. L., Aycard, J. P., Gaydou, E. M., \& Bombard, A. I., (1993). Chemical composition of the essential oil of Hyptis spicigera Lam. Journal of Essential Oil Research, 5, 219-221

Koul, O., (1998). Insect growth inhibition and regulation by allelochemicals: biochemical basis and role in integrated pest management. In Ecological Agriculture and Sustainable Development, vol. 2, ed. by Dhalwal GS et al. Indian Ecological Society and Centre for Research in Rural and Industrial Development, India. pp 93-110.

Mbata, G. N., \& Brewster, C. C., (2009). Functional response of Pteromalus cerealellae (Hymenoptera: Pteromalidae) on the cowpea weevil, Callosobruchus maculatus, and cowpea varietal susceptibility. Biocontrol, 54, 751-761.

Ndomo, A. F., Tapondjou, L. A., Ngamo, L. T., \& Hance, T., (2010). Insecticidal activities of essential oil of Callistemon viminalis applied as fumigant and powder against two bruchids. Journal of Applied Entomology, 134, 333-341. 
Onayade, O. A., Looman, A., Scheffer, J. J. C., Svendsen, A., \& Baerheim, (1990). Composition of the herb essential oil of Hyptis spicigera Lam. Flavour and Flagrance Journal, 5, 101-105.

Ouédraogo, A. P., Sou, S., Sanon, A., Monge, J. P., Huignard, J., Tran, M. D., \& Credland, P. F., (1996). Influence of temperature and humidity on populations of Callosobruchus maculatus (Coleoptera: Bruchidae) and its parasitoid Dinarmus basalis (Pteromalidae) in two zones of Burkina Faso. Bulletin of Entomological Research, 86, 695-702.

Peerzada, N., (1997). Chemical composition of the essential oils of H. suaveolens sp. Molecules, 2, 165-168.

Rahman, M. M., \& Schmidt, G. H., (1999). Effect of Acorus calamus (L.) (Araceae) essential oil vapors from various origins on Callosobruchus phaseoli Gyllenhal (Coleoptera: Bruchidae). Journal of Stored Product Research, 35, 285-295.

Rasplus, J. Y., (1989). Révision des espèces afro tropicales du genre Dinarmus Thomson (Hymenoptera: Pteromalidae). Annales Société Entomologique de France, 25, 135-162.

Risha, M. E., El-Nahal, M. K. A., \& Schmidt, H. G., (1990). Toxicity of vapors of Acorus calamus oil to the immature stages of some stored-product Coleoptera. Journal of Stored Products Research, 26, 133-137.

Sanon, A., Ouedraogo, A. P., Tricault, Y., Credland, P. F., \& Huignard, J., (1998). Biological control of Bruchids in cowpea stores by release of Dinarmus basalis (Hymenoptera: Pteromalidae) adults. Environmental Entomology, 27, 717-725.

Sanon, A., Garba, M., Auger, J., \& Huignard, J., (2002). Analysis of the insecticidal activity of methylisothiocyanate on the Coleoptera Bruchidae Callosobruchus maculatus and its parasitoid Dinarmus basalis (Pteromalidae). Journal of Stored Products Research, 38, 285-295. 
Sanon, A., Ilboudo, Z., Dabiré, L. C. B., Nebie, R. C. H., Dicko, I. O., \& Monge, J. P., (2006a). Effects of Hyptis spicigera Lam. (Labiatae) on the behaviour and development of Callosobruchus maculatus F. (Coleoptera: Bruchidae), a pest of stored cowpeas. International Journal of Pest Management, 52, 117 - 123.

Sanon, A., Dabiré, L. C. B., Huignard, J., \& Monge, J. P., (2006b). Influence of Hyptis suaveolens (Lamiaceae) on the host location behaviour of the parasitoid Dinarmus basalis (Hymenoptera: Pteromalidae). Environmental Entomology, 35, 718-724.

Tchoumbougnang, F., Amvam Zollo, P. H., Fekam Boyom, F., Nyegue, M. A., Bessière, J. M., \& Menut, C., (2005). Aromatic plants of tropical Central Africa. Comparative study of the essential oils of four Hyptis species from Cameroon: H. lanceolata Poit., $H$. pectinata (L.) Poit., H. spicigera Lam. and H. suaveolens Poit. Flavour and Fragrance Journal, 20, 340-343.

Torres, P., Avila, J. G., de Vivar, A. R., Garcia, A. M., Marin, J. C., Aranda, E., \& Cespedes, C. L., (2003). Antioxidant and insect growth regulatory activities of stilbenes and extracts from Yucca periculosa. Phytochemistry, 64, 463-473. 